\title{
$\beta 2$-microglobulin as a marker of systemic lupus erythematosus activity
}

\author{
Iwona Żychowska ${ }^{A-D}$, Dorota Suszek ${ }^{\mathrm{B}-\mathrm{D}},{ }^{\text {, Magdalena Dryglewska }}{ }^{\mathrm{B}, \mathrm{D}}$, Maria Majdan ${ }^{\mathrm{E}, \mathrm{F}}$ \\ Department of Rheumatology and Connective Tissue Diseases, Medical University of Lublin, Poland \\ A - research concept and design; $B$ - collection and/or assembly of data; $C$ - data analysis and interpretation; \\ $\mathrm{D}$ - writing the article; $\mathrm{E}$ - critical revision of the article; $\mathrm{F}$ - final approval of the article
}

\section{Address for correspondence}

Iwona Żychowska

E-mail: izychowska@op.pl

\section{Funding sources}

None declared

\section{Conflict of interest}

None declared

Received on September 22, 2016

Reviewed on December 13,2016

Accepted on January 5, 2017

\begin{abstract}
Background. Systemic lupus erythematosus (SLE) is characterized by alternating periods of activity and remission. A portion of the patients suffers from the chronically active form of the disease. The search for clinically useful markers of its activity is ongoing. At present, it is suggested that B2-microglobulin (B2M) may be useful in assessing SLE activity.

Objectives. The objective of the paper was to investigate the relationship between serum $\beta 2 M$ concentration and SLE activity.

Material and methods. The study group consisted of 69 SLE patients ( 62 women and 7 men), aged $34.5 \pm 11$ years (19-69). Patients with kidney failure and infection were excluded from the study group. The concentration of $\beta 2 M$ was measured using an ELISA test. SLE activity was assessed with Systemic Lupus Erythematosus Disease Activity Index 2000 (SLEDAl-2K), and by measuring the levels of (3 and C 4 complement components, anti-double stranded DNA antibodies (anti-dsDNA antibodies) and $32 \mathrm{M}$. The relationship between $\beta 2 \mathrm{M}$ and the clinical manifestation of SLE was also covered in the study.

Results. The study revealed a statistically significant correlation between $\beta 2 M$ concentration and SLEDAI-2K disease activity index $(p<0.05 ; r=0.6)$, anti-dsDNA titer $(p<0.05 ; r=0.3)$, and $(4$ component serum level $(p<0.05 ; r=-0.3)$. $\beta 2 M$ concentration was significantly higher in patients with arthritis and/or myositis $(p=0.005)$, vasculitis $(p=0.005)$, and hematological manifestations of SLE $(p=0.02)$.
\end{abstract}

Conclusions. Periodical determination of $\beta 2 \mathrm{M}$ concentration in SLE patients may prove helpful in assessing the disease activity.

Key words: systemic lupus erythematosus, disease activity, B2-microglobulin

DOI

10.17219/acem/68291

\section{Copyright}

Copyright by Author(s)

This is an article distributed under the terms of the

Creative Commons Attribution Non-Commercial License

(http://creativecommons.org/licenses/by-nc-nd/4.0/) 


\section{Introduction}

Systemic lupus erythematosus (SLE) is an autoimmune disease leading to chronic inflammation of numerous tissues and organs. The pathogenesis of SLE is complex and associated, i.a., with excessive activation of $\mathrm{T}$ and $\mathrm{B}$ cells, apoptosis impairment, and inadequate immune complex clearance. Excessive B cell activation results in the overproduction of autoantibodies, which combine with chromatin, creating immune complexes and inducing inflammation. ${ }^{1}$ In daily practice, SLE activity is evaluated with the use of standardized disease activity assessment tools: Systemic Lupus Erythematosus Disease Activity Index 2000 (SLEDAI-2K), British Isles Lupus Assessment Group (BILAG), and by verifying the laboratory parameters: $\mathrm{C} 3$ and $\mathrm{C} 4$ complement components, anti-C1q antibodies, anti-double stranded DNA antibodies (anti-dsDNA titer). ${ }^{2-4}$

In Polish conditions, circulating anti-C1q antibodies have been recently studied as the marker for lupus nephritis, while anti-ribosomal $\mathrm{P}$ protein antibodies titer and IL-10 concentration in exhaled breath condensate as general markers of the disease activity. ${ }^{5-7}$

The search for new SLE activity markers is ongoing. In recent years, the effectiveness of marking the $\beta 2$-microglobulin $(\beta 2 \mathrm{M})$ serum concentrations in monitoring SLE activity has been consistently highlighted. $\beta 2 \mathrm{M}$ is a lowmolecular-weight protein found on the surface of nucleated cells, including lymphocytes and macrophages. As a result of $\mathrm{T}$ and $\mathrm{B}$ cells activation, $\beta 2 \mathrm{M}$ is released, resulting in the elevation of its serum concentration level. The increased concentration of the protein is found chiefly in patients suffering from lymphoproliferative diseases, kidney failure and autoimmune diseases. ${ }^{8,9}$ So far, few studies have been carried out that have tackled the relationship between SLE activity and $\beta 2 \mathrm{M}$ blood concentration. ${ }^{10-13}$

\section{Patients and methods}

The study was carried out on a group of 69 SLE patients (62 women and 7 men) aged $34.5 \pm 11$ years (19-69), hospitalized at the Department of Rheumatology and
Connective Tissue Diseases of the Medical University of Lublin between 2013 and 2014. All patients met the 1997 SLE diagnosis criteria of the American College of Rheumatology. The average disease duration was $5.8 \pm 4.8$ years (0.5-19). Mucocutaneous symptoms were found in $22 \mathrm{pa}-$ tients $(31.9 \%)$, arthritis in 7 patients $(10.1 \%), 8$ patients (11.6\%) were diagnosed with lupus nephritis, hematological symptoms were found in 6 patients (8.7\%), and vasculitis in 8 patients (11.6\%). None of the patients were diagnosed with nervous system disorder or serositis. Patients suffering from infection, cancer and kidney failure were excluded from the study group.

In all the patients, SLE activity was assessed through checking the concentration of $\mathrm{C} 3$ and $\mathrm{C} 4$ components, anti-dsDNA antibodies and $\beta 2 \mathrm{M}$, as well as using SLEDAI-2K. $\beta 2 \mathrm{M}$ serum concentration was measured using an ELISA test. C3 and C4 components levels were measured by turbidimetry, and anti-dsDNA antibodies concentration was determined by ELISA.

The statistical analysis was done using STATISTICA v. 10.0 software (StatSoft, Kraków, Poland). All data was given as means \pm SD. Nonparametric tests were used: the Mann-Whitney U test and Spearman's rank correlation coefficient. Differences were considered significant at $\mathrm{p}<0.05$.

\section{Results}

Table 1 shows the selected parameters of disease activity assessment in the group of SLE patients. The study group revealed a statistically significant correlation between $\beta 2 \mathrm{M}$ concentration and anti-dsDNA antibodies titer $(\mathrm{p}<0.05$; $\mathrm{r}=0.3)$, C4 component $(\mathrm{p}<0.05 ; \mathrm{r}=-0.3)$, and SLEDAI-2K $(\mathrm{p}<0.05 ; \mathrm{r}=0.6$ ) (Fig. 1-3). No significant relationship was found between $\beta 2 \mathrm{M}$ and $\mathrm{C} 3$ component, the patients' age or the duration of the disease.

Table 2 presents mean concentrations of $\beta 2 \mathrm{M}$ in SLE patients with different clinical manifestations of the disease. $\beta 2 \mathrm{M}$ concentration was significantly higher in patients with

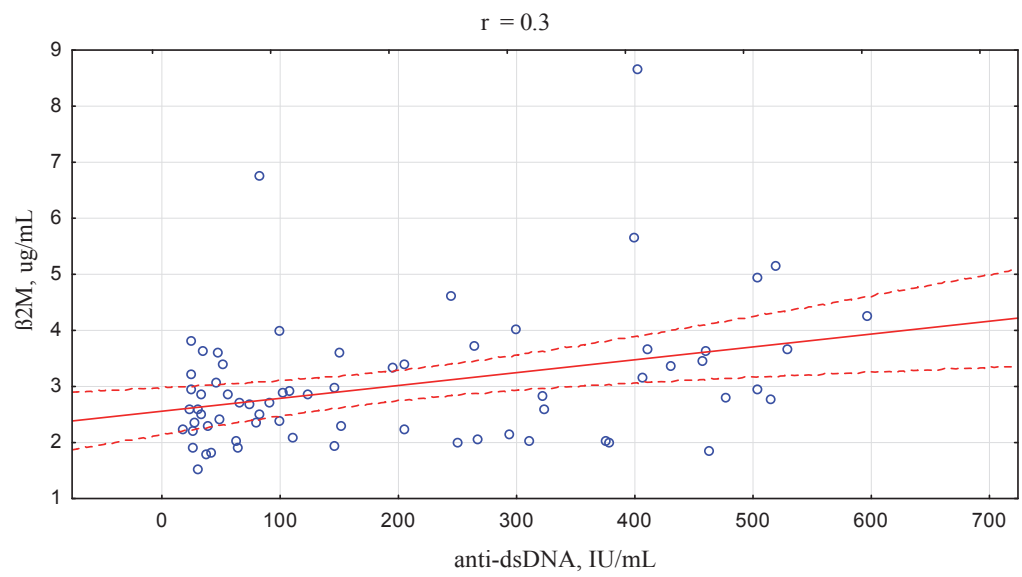

Fig. 1. The correlation between $\beta 2 \mathrm{M}$ concentration and anti-dsDNA antibodies titer

anti-dsDNA - anti-double stranded DNA antibodies; $\beta 2 \mathrm{M}-\beta 2$-microglobulin. 


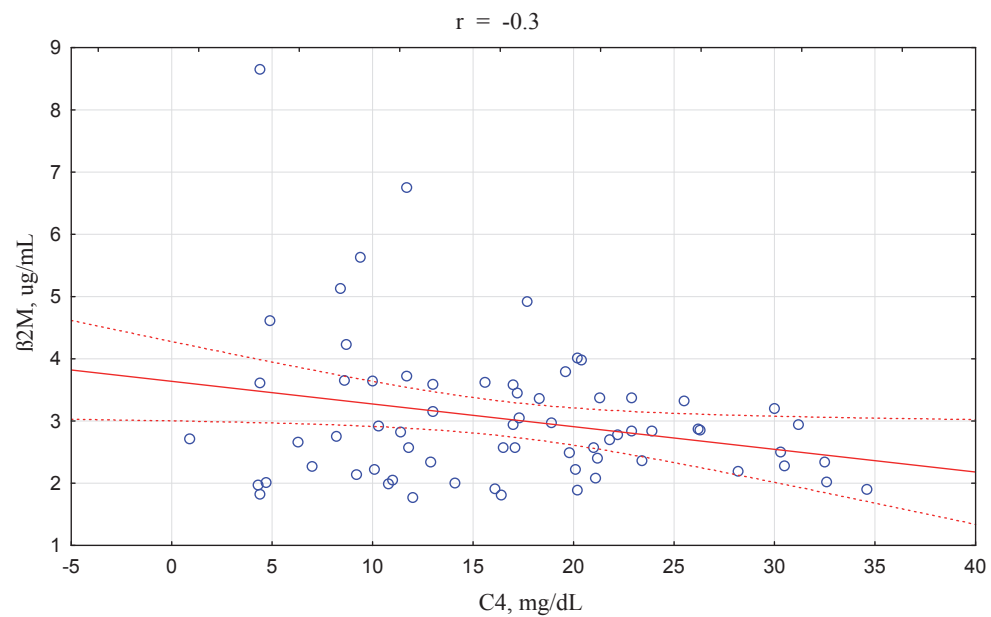

Fig. 2. The correlation between $\beta 2 \mathrm{M}$ concentration and $C 4$ component

$\beta 2 \mathrm{M}$ - $\beta 2$-microglobulin; C4 - C4 complement.

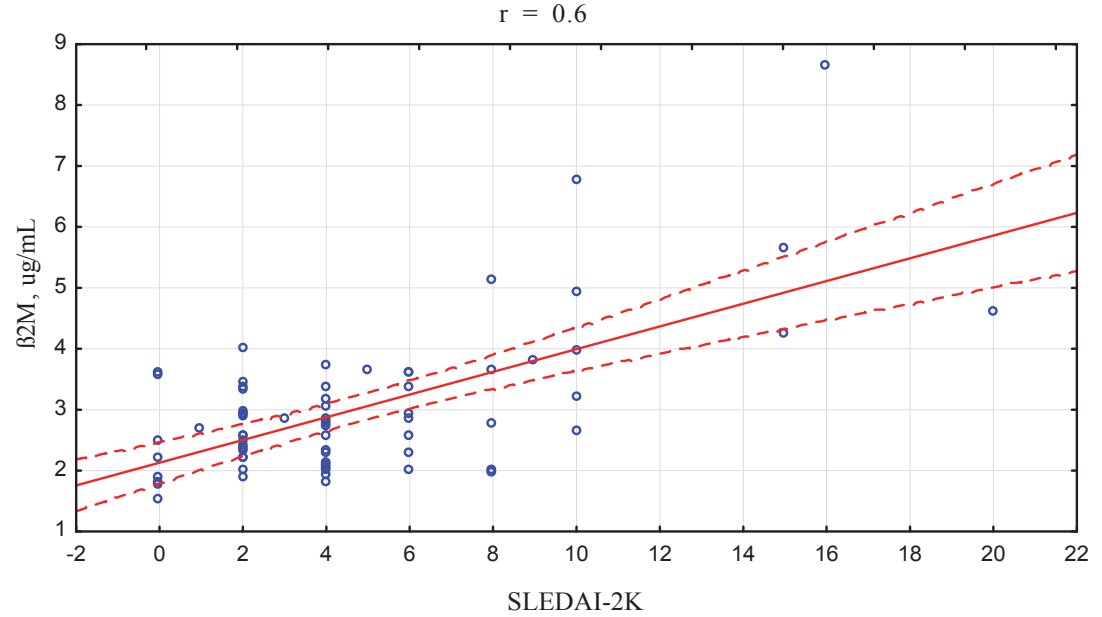

Fig. 3. The correlation between $\beta 2 \mathrm{M}$ concentration and SLEDAI-2K

$\beta 2 \mathrm{M}$ - $\beta 2$-microglobulin; SLEDAI-2K - Systemic Lupus Erythematosus Disease Activity Index 2000

Table 1. Selected markers of disease activity in SLE patients

\begin{tabular}{|c|c|c|c|}
\hline $\begin{array}{c}\text { Disease activity } \\
\text { parameters }\end{array}$ & $\begin{array}{c}\text { Mean } \\
\text { value } \pm S D\end{array}$ & Range & $\begin{array}{l}\% \text { positive } \\
\text { results }\end{array}$ \\
\hline $\begin{array}{l}\text { anti-dsDNA [IU/mL] } \\
(\text { positive }>60)\end{array}$ & $200.2 \pm 175.1$ & $18.5-597.2$ & 34 (49.3\%) \\
\hline $\begin{array}{l}\text { C3 [mg/dL] } \\
\text { (norm 12-36) }\end{array}$ & $86.8 \pm 22.9$ & $33.5-134.0$ & $36(52.2 \%)$ \\
\hline $\begin{array}{l}\text { C4 [mg/dL] } \\
\text { (norm 90-170) }\end{array}$ & $16.6 \pm 8.2$ & $0.9-34.6$ & $23(33.3 \%)$ \\
\hline $\begin{array}{l}\beta 2 \mathrm{M}[\mu \mathrm{g} / \mathrm{mL}] \\
\text { (norm 0-3) }\end{array}$ & $3.0 \pm 1.2$ & $1.8-8.6$ & $24(34.8 \%)$ \\
\hline SLEDAI-2K & $4.7 \pm 4.1$ & $0-20$ & - \\
\hline
\end{tabular}

anti-dsDNA - anti-double stranded DNA antibodies; $\beta 2 \mathrm{M}$ - $\beta 2$-microglobulin; C3 - C3 complement components; C4 - C4 complement components; SLE - systemic lupus erythematosus; SLEDAI-2K - Systemic Lupus Erythematosus Disease Activity Index 2000

arthritis and/or myositis $(\mathrm{p}=0.005)$, vasculitis $(\mathrm{p}=0.005)$ and hematological manifestations of SLE $(p=0.02)$.

No statistically significant deviation of $\beta 2 \mathrm{M}$ concentration was found in patients suffering from cutaneous and/or mucosal manifestations or kidney damage (Table 2).
Table 2. Comparison of $\beta 2 M$ concentration in patients with different SLE clinical manifestations

\begin{tabular}{|c|c|c|}
\hline SLE manifestations & $\begin{array}{c}\text { Mean concentration } \\
\text { of } \beta 2 M \pm S D\end{array}$ & $p$-value \\
\hline $\begin{array}{l}\text { Cutaneous and/or mucosal } \\
\qquad \begin{array}{l}(+), n=22 \\
(-), n=47\end{array}\end{array}$ & $\begin{array}{l}3.2 \pm 1.2 \\
2.9 \pm 1.2\end{array}$ & ns \\
\hline $\begin{array}{l}\text { Vasculitis } \\
\qquad(+), n=8 \\
(-), n=61\end{array}$ & $\begin{array}{l}4.7 \pm 1.8 \\
2.8 \pm 0.9\end{array}$ & 0.005 \\
\hline $\begin{array}{l}\text { Arthritis and/or myositis } \\
\qquad(+), n=7 \\
(-), n=62\end{array}$ & $\begin{array}{l}4.9 \pm 2.2 \\
2.8 \pm 0.8\end{array}$ & 0.005 \\
\hline $\begin{array}{l}\text { Serositis } \\
\qquad \begin{array}{l}(+), n=0 \\
(-), n=69\end{array}\end{array}$ & $\begin{array}{l}- \\
-\end{array}$ & - \\
\hline $\begin{array}{l}\text { Kidney } \\
\qquad(+), n=8 \\
(-), n=61\end{array}$ & $\begin{array}{l}2.7 \pm 0.6 \\
3.0 \pm 1.2\end{array}$ & ns \\
\hline $\begin{array}{l}\text { Neurological } \\
\qquad \begin{array}{l}(+), n=0 \\
(-), n=69\end{array}\end{array}$ & - & - \\
\hline $\begin{array}{l}\text { Hematological } \\
\begin{array}{l}(+), n=6 \\
(-), n=63\end{array}\end{array}$ & $\begin{array}{l}3.8 \pm 1.0 \\
2.8 \pm 1.2\end{array}$ & 0.02 \\
\hline
\end{tabular}

$\beta 2 \mathrm{M}$ - $\beta 2$-microglobulin; SLE - systemic lupus erythematosus; ns - nonsignificant. 


\section{Discussion}

Considerable importance has been attached recently to early detection of SLE exacerbation and to monitoring its activity. The search for sensitive markers of the disease activity continues to enable anticipation of exacerbation at the preclinical stage. The significance of $\beta 2 \mathrm{M}$ in monitoring SLE activity has been highlighted lately. This study revealed that increased $\beta 2 \mathrm{M}$ level was found in $34.8 \%$ of the patients, and correlated with the disease activity markers such as SLEDAI-2K, anti-dsDNA antibodies titer, and $\mathrm{C} 4$ component. Considerably higher $\beta 2 \mathrm{MG}$ levels were found in patients with musculoskeletal system involvement, hematological symptoms and vasculitis.

The study by Kim et al., conducted on 100 SLE patients, revealed increased $\beta 2 \mathrm{M}$ concentration in $97 \%$ of patients. $\beta 2 \mathrm{M}$ concentration was significantly higher in patients with serositis, oral erosions and symptoms of lupus nephritis. Much like in the case of the study described in the present paper, a statistically significant correlation was found between $\beta 2 \mathrm{M}$ and anti-dsDNA antibodies titer, C3 component and hemoglobin concentration, and SLEDAI disease activity score. ${ }^{10}$ Hermansen et al. examined 26 SLE patients and proved the relationship between $\beta 2 \mathrm{M}$ concentration and disease activity scored according to SLEDAI, C3 complement component and daily proteinuria. They also found a significant correlation between the concentration of $\beta 2 \mathrm{M}$ and cytokines responsible for SLE pathogenesis: IL-6, IL-8, IL-10, IL-18, IFN- $\alpha .{ }^{11}$ Similar results were obtained by Skare et al. - in a group of 129 SLE patients, $\beta 2 \mathrm{M}$ concentration correlated with SLEDAI, $\mathrm{OB}$, anti-dsDNA antibodies, and C3. ${ }^{12}$ Wakabayashi et al. proved that $\beta 2 \mathrm{M}$ concentration decreased throughout the course of immunosuppressive treatment. ${ }^{13}$

The cause of elevated $\beta 2 \mathrm{M}$ concentration in SLE patients is not fully understood. Some researchers suggest the $\beta 2 \mathrm{M}$ increase may result from increased lymphocyte turnover in autoimmune disease, or the presence of immune complexes formed by $\beta 2 \mathrm{M}$ with anti- $\beta 2 \mathrm{M}$ antibodies removed by kidneys. ${ }^{10,14,15}$ An experimental study on diseased SLE mice with $\beta 2 \mathrm{M}$ deficiency revealed differences in the clinical picture of the disease - a higher percentage of mice with cutaneous symptoms, with a lower percentage of kidney damage. The results suggest a possible influence of $\beta 2 \mathrm{M}$ on the clinical course of SLE. ${ }^{16}$
The number of studies assessing the significance of $\beta 2 \mathrm{M}$ in monitoring SLE activity is scarce. So far, only a small group of patients has been studied, with very few studies focused on the influence of treatment on $\beta 2 \mathrm{M}$ concentration. The authors consider it viable to include $\beta 2 \mathrm{M}$ in the process of assessing SLE activity, and to monitor $\beta 2 \mathrm{M}$ concentration in the same patients over different disease activity periods.

\section{References}

1. Kyttaris VC, Krishnan S, Tsokos GC. Systems biology in systemic lupus erythematosus: Integrating genes, biology and immune function. Autoimmunity. 2006;39:705-709.

2. Gladman DD, Ibenz D, Urowitz MB. Systemic Lupus Erythematosus Disease Activity Index 2000. J Rheumatol. 2002;29:288-291.

3. Gordon C, Sutcliffe N, Skan J, Stoll T, Isenberg DA. Definition and treatment lupus flares measured by the BILAG index. Rheumatology. 2003;42:1372-1379.

4. Trendelenburg M. Antibodies against $\mathrm{C} 1 \mathrm{q}$ in patients with systemic lupus erythematosus. Springer Semin Immunopathol. 2005;27:276-285.

5. Smykał-Jankowiak K, Niemir ZI, Polcyn-Adamczak M. Do circulating antibodies against C1q reflect the activity of lupus nephritis? Pol Arch Med Wewn. 2011;121:287-295.

6. Olesińska M, Chwalińska-Sadowska H, Wiesik-Szewczyk E, Mielnik P, Zabek J. Clinical manifestation of systemic lupus erythematosus in patients with antiribosomal P protein antibodies. Pol Arch Med Wewn. 2010;120:76-81.

7. Nielepkowicz-Goździńska A, Fendler W, RobakE, et al. Exhaled cytokines in systemic lupus erythematosus with lung involvement. Pol Arch Med Wewn. 2013;123:141-148.

8. Evrin PE, Strom T. Beta 2-microglobulin and its binding activity in serum from patients with SLE. Ann Rheum Dis. 1984;43:267-274.

9. Bień E, Balcerska A. Znaczenie kliniczne $\beta 2$-mikroglobuliny w chorobie nowotworowej u dorosłych i dzieci. Współcz Onkol. 2003;7:333-338.

10. Kim HA, Jeon JY, Yoon JM, Suh CH. Beta 2-microglobulin can be a disease activity marker in systemic lupus erythematosus. Am J Med Sci. 2010;339:337-340.

11. Hermansen ML, Hummelshøj L, Lundsgaard D, et al. Increased serum $\beta 2$-microglobulin is associated with clinical and immunological markers of disease activity in systemic lupus erythematosus. Lupus. 2012;21:1098-1104.

12. Skare TL, Ferri K, Santos MA. Systemic lupus erythematosus activity and beta two microglobulin levels. Sao Paulo Med J. 2014;132:239-242.

13. Wakabayashi K, Inokuma S, Matsubara E, et al. Serum $\beta 2$-microglobulin level is a useful indicator of disease activity and hemophagocytic syndrome complication in systemic lupus erythematosus and adultonset Still's disease. Clin Rheumatol. 2013;32:999-1005.

14. Ooi BS, Ooi YM, Pesce AJ, Pollak VE. Antibodies to beta 2-microglobulin in the sera of patients with systemic lupus erythematosus. Immunology. 1977;33:535-341.

15. Revillard JP, Vincent C, Rivera S. Anti-beta2-microglobulin lymphocytoxic autoantibodies in systemic lupus erythematosus. J Immunol. 1979;122:614-618.

16. Chan OT, Paliwal V, McNiff JM, Park SH, Bendelac A, Shlomchik MJ. Deficiency in beta2-microglobulin, but not CD1, accelerates spontaneous lupus skin disease while inhibiting nephritis in MRL-Fas (Ipr) mice: An example of disease regulation at the organ level. J Immunol. 2001;167:2985-2990. 